\title{
Perancangan dan Implementasi Sistem Informasi Kesehatan P - IRT berbasis Web dan Android
}

\author{
http://dx.doi.org/10.28932/jutisi.v6i2.2457
}

\author{
Yan Rigid Wijaya $^{\# 1}$, Radius Tanone $\mathrm{\varpi}^{\otimes_{2}}$ \\ ${ }^{\#} J u r u s a n$ Teknik Informatika, Universitas Kristen Satya Wacana \\ Jl. Dr. O. Notohamidjojo, Kel. Blotongan, Kec. Sidorejo, Salatiga \\ ${ }^{1}$ rigid.212@gmail.com \\ *Jurusan Teknik Informatika, Universitas Kristen Satya Wacana \\ Jl. Dr. O. Notohamidjojo, Kel. Blotongan, Kec. Sidorejo, Salatiga \\ ${ }^{2}$ radius.tanoneduksw. edu
}

\begin{abstract}
The Salatiga City Government through the Health Office organizes a system of services and socialization to the community in a preventive manner. The intended community includes P-IRT (Food and Home Industry) which constitutes the food and beverage industry sector which is included in the small industry. In carrying out the delivery of information, employees must carry out a program of training activities as well as by conducting socialization to the community directly, where it is more time consuming, costly, and energy. This also makes the service and delivery of information less efficient. Therefore a web-based and mobile-based information system design is needed to complement these shortcomings. By using the Laravel Framework and Android Programming as well as a collaborative filter algorithm, a web-based application and an Android phone are generated to address the problem. Sharing information and discussions between the public and related agencies is easier to use this system.
\end{abstract}

Keywords - Health Office; Home Industry; Information System; Web; Android

\section{Pendahuluan}

Pemerintah Kota Salatiga melalui Dinas Kesehatan menyelenggarakan sistem pelayanan dan sosialisasi kepada masyarakat secara preventif. Hal ini termasuk pelayanan kepada P-IRT (Pangan dan Industri Rumah Tangga). P-IRT (Pangan dan Industri Rumah Tangga) merupakan sebuah bidang industri produksi makanan dan minuman yang termasuk di dalam lingkup industri kecil atau berbasis rumah tangga [1]. Dalam pelaksanaan penyampaian informasi, pegawai harus mengadakan suatu program kegiatan pelatihan secara langsung maupun dengan melakukan sosialisasi terhadap masyarakat secara langsung, dimana hal tersebut lebih memakan waktu, biaya, dan tenaga. Hal ini juga membuat pelayanan dan penyampaian informasi kurang efektif dan efisien. Apalagi jika jumlah masyarakat banyak dan berbeda lokasi atau tempat tinggal.
Sehingga diperlukan sebuah rancangan sistem informasi berbasis web dan mobile untuk melengkapi kekurangan tersebut. Waktu dan biaya merupakan alasan pertama yang mendasari dari dibentuknya aplikasi, karena pada metode sebelumnya hal tersebut memerlukan sebuah persiapan dan agenda yang harus dibentuk dalam kinerja perkembangan informasi kesehatan terhadap masyarakat terkhusus pada pemilik industri P-IRT. Kendala biaya yang telah disebutkan meliputi biaya sewa tempat, biaya konsumsi, honor pemateri, dan lain-lain. Sehingga demi kelancaran dan penghematan proses penyampaian informasi tersebut dibangunlah sebuah sistem informasi berbasis website dan android yang bertujuan untuk melayani masyarakat dan juga pemilik usaha P-IRT yang membutuhkan sebuah informasi kesehatan melalui sebuah media online.

Berdasarkan pemaparan di atas maka rumusan masalah dari penelitian ini yaitu bagaimana merancang sistem informasi berbasis web dan mobile android agar dapat membantu keterlibatan masyarakat dalam bidang kesehatan P-IRT. Adapun tujuan penelitian ini yaitu untuk menunjang fasilitas kinerja pada Dinas Kesehatan Kota Salatiga tanpa harus mengalokasikan beberapa unsur yang berkaitan dengan pembiayaan yang banyak dan membutuhkan waktu yang kurang efisien. Pada penelitian ini akan dibahas perancangan dan implementasi dari sebuah Sistem Informasi Kesehatan PIRT (Pangan dan Industri Rumah Tangga) pada instansi pemerintah, yang diharapkan mempermudah untuk penyampaian materi P-IRT, konsultasi, dan penyuluhan tentang kesehatan P-IRT dengan cara yang lebih efektif dan efisien. Secara umum sistem yang akan dirancang berbentuk blog yang berisi teks, gambar dan forum diskusi. Framework Laravel adalah salah satu framework yang dapat digunakan dalam membangun aplikasi website sistem informasi yang berbentuk blog narasi dan gambar yang cukup populer digunakan oleh para developer [2]. 
Dalam perancangan website yang akan digunakan ini juga menerapkan algoritma Collaborative Filtering dalam mendukung rekomendasi bacaan atau informasi kepada masyarakat. Metode tersebut merupakan sebuah solusi penggunaan rekomendasi berdasarkan perilaku pengguna dengan pemanfaatan metode penyaringan. Metode Collaborative Filtering memberikan rekomendasi hasil yang berbeda untuk setiap pengguna berdasarkan peringkat hasil yang telah diberikan kepada setiap produk [3]. Arti dari produk dalam sistem informasi ini adalah materi tentang kesehatan P-IRT yang sudah dikelola oleh pihak instansi pemerintah ke dalam daftar bacaan yang dikelompokkan dalam beberapa kategori yang mengacu pada jumlah kriteria permasalahan yang sedang dibahas. Sehingga calon pembaca akan diarahkan kedalam suatu kategori dari sebuah informasi berdasarkan level tertentu. Setelah mendapatkan penjelasan mengenai gambaran sistem informasi yang akan dirancang tersebut, maka penelitian ini diharapkan mampu memberikan solusi terbaik sebagai sarana media elektronik yang bersumber dari pihak yang telah berkompeten pada bidang ahli kesehatan P-IRT di Dinas Kesehatan Kota Salatiga. Selain itu, pada perancangan sistem ini akan dirancang juga dengan versi mobile android.

\section{KAJIAN PUSTAKA}

Penelitian yang telah membahas tentang konsep dan teori Framework Laravel mengatakan bahwa Framework Laravel adalah suatu struktur konseptual dasar yang digunakan untuk memecahkan atau menangani suatu masalah yang kompleks dalam pembuatan website. Singkatnya, framework adalah wadah atau kerangka kerja dari sebuah website yang akan dibangun, sehingga suatu aplikasi yang terdiri dari baris kode memiliki struktur data yang memiliki keterikatan parameter fungsi untuk menentukan sebuah proyeksi yang akan berjalan dengan bahasa pemrograman. Dengan menggunakan kerangka tersebut waktu yang digunakan dalam membuat website lebih singkat dan memudahkan dalam melakukan perbaikan. Salah satu framework yang banyak digunakan oleh programmer adalah Framework Laravel. Laravel adalah framework berbasis PHP yang sifatnya open source, dan menggunakan konsep model - view - controller. Laravel berada di bawah lisesni MIT License dengan menggunakan Github sebagai tempat berbagi code dan menjalankannya [4].

Selanjutnya tentang pengenalan aplikasi android, pada awalnya android merupakan sistem operasi besutan dari google yang dikhususkan pada ponsel atau smartphone, namun seiring perkembangan jaman sistem operasi ini tidak hanya digunakan atau diperuntukan untuk smartphone saja namun juga berbagai jenis peralatan maupun aksesoris elektronik rumah tangga lainnya. Sistem operasi android pada umumnya merupakan sistem operasi open source atau bersifat terbuka sehingga para pengguna dapat dengan mudah menggunakannya maupun memodifikasi sistem tersebut [5].

Penelitian selanjutnya telah membahas tentang manfaat dari internet dan aplikasi sistem informasi dalam mencari sebuah informasi. Salah satu pemanfaatan teknologi jaman sekarang adalah melalui internet. Internet merupakan sebuah teknologi yang dirancang untuk memenuhi kebutuhan manusia dalam skala besar dan jangkauan yang luas. Di dalam internet tersebut seseorang dapat mengakses sebuah web appliaction. Web application adalah software yang berjalan melalaui web server didalam sebuah jaringan internet. Lain halnya dengan aplikasi desktop yang dapat dijalankan secara langsung melalui sistem operasi dalam komputer, web application hanya bisa diakses melalui web browser. Web application memiliki beberapa keuntungan dibandingkan dengan aplikasi desktop, yaitu dapat dijalankan dimanapun sebuah perangkat terdapat web browser untuk mengaksesnya [6].

Penelitian selanjutnya telah membahas pentingnya peranan teknologi internet dan sistem informasi dalam mempelajari ilmu pengetahuan dan komunikasi dengan baik. Sistem informasi merupakan sebuah teknologi interaktif yang dapat digunakan sebagai sarana informasi yang dapat diakses oleh semua pihak, baik pihak umum maupun pihak yang mempunyai hak akses [7].

Penelitian selanjutnya dengan judul "Aplikasi Kuliner Salatiga Berbasis Web Menggunakan Framework Laravel" telah membahas tentang informasi kuliner yang ada di Kota Salatiga terutama dalam bidang teknologi web. Berdasarkan penelitian, pembahasan dan pengujian yang dilakukan, maka dapat disimpulkan bahwa sebuah sistem informasi aplikasi kuliner Salatiga dapat membantu pedagang dalam memasarkan makanannya. Selain itu, aplikasi ini dapat mempermudah pecinta makanan dalam mencari dan menemukan informasi seputar makanan dan lokasi penjualnya. Penggunaan Framework Laravel membantu dalam pengembangan aplikasi ini dan penggunaan blade yang merupakan template engine bawaan dari laravel memudahkan dalam pengaturan layout [8].

Terkait dengan PIRT itu sendiri, sebuah penelitian lain yang berjudul dan membahas tentang "Pengembangan Sistem Keamanan Pangan Terpadu Dalam Mewujudkan Efektivitas Implementasi Izin Edar Produk Pangan Industri Rumah Tangga (PIRT)" telah membahas tentang proses yang berjalan dalam lingkup pasar industri rumah tangga dengan berbagai izin edar yang sesuai dengan ketentuan UU yang disahkan oleh pemerintah dan berbagai instansi terkait. Sertifikasi izin edar tersebut merupakan sebuah bentuk legalisasi yang dikeluarkan oleh pemerintah maupun pihak berwenang untuk memberikan jaminan kesehatan terhadap masyarakat maupun pelaku usaha P - IRT [9].

Berdasarkan dengan penelitian-penelitian yang telah dilakukan terkait dengan perkembangan kesehatan P-IRT, Framework Laravel, sistem informasi berbasis website, serta aplikasi berbasis android maka dilakukan penelitian lanjutan yang membahas tentang perancangan dan implementasi sistem informasi kesehatan pangan dan industri rumah tangga berbasis web dan android (studi kasus Dinas Kesehatan Kota Salatiga). Apabila mengkaji ulang dari penelitian sebelumnya, maka penggunaan Framework Laravel sebagai 
teknologi framework untuk membangun sebuah sistem informasi sangatlah membantu para pengembang aplikasi sehingga dapat memberikan kontribusi yang baik untuk pengembangan sistem informasi, dan berbagai jenis aplikasi website yang lain. Pada rancangan sistem informasi yang akan dibuat, penggunaan framework adalah sebuah hal utama dalam menyelesaikan seluruh rancangan hingga menjadi bentuk aplikasi. Selain dari itu, penelitian kali ini juga membuat rancangan dengan versi mobile menggunakan platform Android Studio. Platform android juga merupakan salah satu teknologi yang praktis dan mudah digunakan oleh masyarakat, android merupakan teknologi yang mudah diaplikasikan sehari-hari dan dimodifikasi atau dirancang sesuai kebutuhan pengguna.

\section{METODE PENELITIAN}

Metode penelitian merupakan bagian gambaran sebuah rancangan dan sekumpulan data yang akan dijelaskan terhadap sebuah pokok permasalahan yang dilakukan pada bab pembahasan. Metode penelitian merupakan cara ilmiah untuk mendapatkan data dengan tujuan dan kegunaan tertentu [10]. Terdapat dua macam metode penelitian yaitu kuantitatif dan kualitatif. Metode kuantitatif adalah metode dimana sebuah data mengacu pada suatu nilai yang nyata atau data tersebut memiliki jumlah nominal angka yang dapat dinilai secara besaran bentuknya. Namun pada metode kali ini, tidak menggunakan pendekatan kuantitatif, karena dalam penelitian ini tidak membahas sebuah analisa suatu jumlah apapun maupun suatu populasi yang terhitung, melainkan sebuah penelitian yang membahas mengenai rancangan dan implementasi dari sebuah aplikasi sistem informasi yang dibangun. Metode penelitian kualitatif adalah metode penelitian yang berlandaskan pada filsafat postpositivisme, digunakan untuk meneliti pada kondisi obyek yang alamiah, (sebagai lawannya adalah eksperimen) dimana peneliti sebagai instrumen kunci, pengambilan sampel sumber data dilakukan secara purposive dan snowball, teknik pengumpulan dengan triangulasi (gabungan), analisis data bersifat induktif / kualitatif, dan hasil penelitian kualitatif lebih menekankan makna daripada generalisasi. Dapat disimpulkan dari pengertian tersebut bahwa penelitian melalui pendekatan kualitatif itu berlandaskan falsafah postpositivisme dan peneliti sebagai instrumen kunci dalam penelitian tersebut [11].

Dari penjelasan metode kualitatif tersebut dapat disimpulkan bahwa penelitian ini dilakukan terhadap suatu objek kebutuhan terhadap masyarakat dalam bentuk pelayanan melalui sistem informasi. Maka dalam metode penelitian yang dilakukan menggunakan pendekatan kualitatif karena dalam pembangunan sebuah sistem informasi yang telah dilakukan memiliki makna dan tujuan sebagai sarana yang dapat digunakan dalam mempermudah sebuah pelayanan terhadap masyarakat melalui instansi pemerintah. Salah satu metode yang digunakan dalam penelitian ini adalah metode prototype seperti yang terlihat pada gambar 1 dibawah ini.

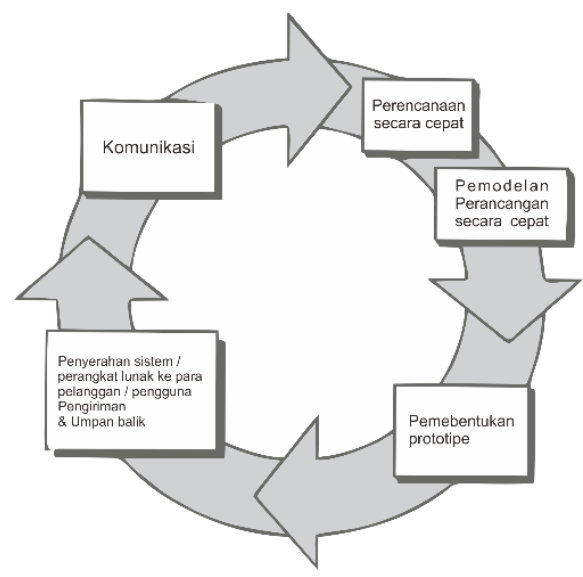

Gambar 1. Metode Prototype

Gambar 1 merupakan gambaran tahapan-tahapan yang dilalui dalam sebuah metode prototype. Adapun tahapantahapan tersebut beserta penjelasannya sebagai berikut:

1. Komunikasi dan pengumpulan data awal, yaitu analisis terhadap kebutuhan pengguna.

2. Quick design (desain cepat), yaitu pembuatan desain secara umum untuk dievaluasi lebih dalam kembali.

3. Pembentukan prototype, yaitu pembuatan perangkat prototype termasuk pengujian dan penyempurnaan sistem.

4. Evaluasi terhadap prototype, yaitu mengevaluasi prototype dan menganalisis terhadap kebutuhan pengguna secara lebih detail.

5. Perbaikan prototype, yaitu pembuatan tipe yang sebenarnya berdasarkan hasil dari evaluasi prototype.

6. Produksi akhir, yaitu memproduksi perangkat secara benar sehingga dapat digunakan oleh pengguna [12].

Sedangkan tahapan-tahapan dalam perancangan sistem meliputi:

1. Identifikasi Masalah : Pada tahap ini dilakukan analisis terhadap permasalahan yang ada, terkait dengan proses pembangunan sistem informasi yang dibutuhkan oleh Dinas Kesehatan Kota Salatiga. Proses tersebut berupa tahapan perencanaan dan diskusi terhadap desain sistem, fitur-fitur yang dibutuhkan, dan data apa saja yang ditampilkan.

2. Studi Literatur : Pada tahap ini dilakukan pengumpulan terhadap jurnal dan karya ilmiah terdahulu, dan beberapa konsep pembangunan sistem informasi, jurnal yang membahas tentang P-IRT, serta sumber 
mengenai pembahasan terkait penelitian menggunakan Framework Laravel 5.5 dan android.

3. Pengumpulan Data : Pada tahap ini dilakukan pengumpulan data-data yang diperlukan untuk penelitian, Data-data yang diperlukan yaitu hal-hal yang akan ditampilkan pada sistem mengenai seputar kesehatan P - IRT serta kategori suatu berita dan materi kesehatan P-IRT.

4. Perancangan Sistem : Tahapan ini merupakan proses pembuatan sistem sebagai tugas utama, dengan menggunakan PHP versi 7.3, database MySQL dan Framework Laravel 5.5 sampai menjadi sebuah website. Sselain versi yang disediakan melalui website pada aplikasi ini juga tersedia versi android dimana tool yang digunakan dalam membangun aplikasi versi mobile android adalah Android Studio.

5. Pengujian Sistem : Pada tahap ini dilakukan pengujian sistem yang sudah jadi apakah bisa berjalan pada server dengan baik dan sesuai dengan kebutuhan user. Apabila belum sesuai, maka akan dilakukan perbaikan sampai sistem atau program bisa berjalan sesuai dengan kebutuhan user.

6. Penulisan Laporan : Hasil akhir dari semua yang telah dilakukan selama penelitian dan hasil yang telah didapatkan selama penelitian.

Sistematika proses yang ada dalam penelitian rancangan sistem informasi ini dilengkapi dengan Undefined Model Language (UML), gunanya yaitu memberikan gambaran secara visual terhadap fitur-fitur yang tertanam pada sistem. Antara lain : usecase diagram, activity diagram, dan class diagram.

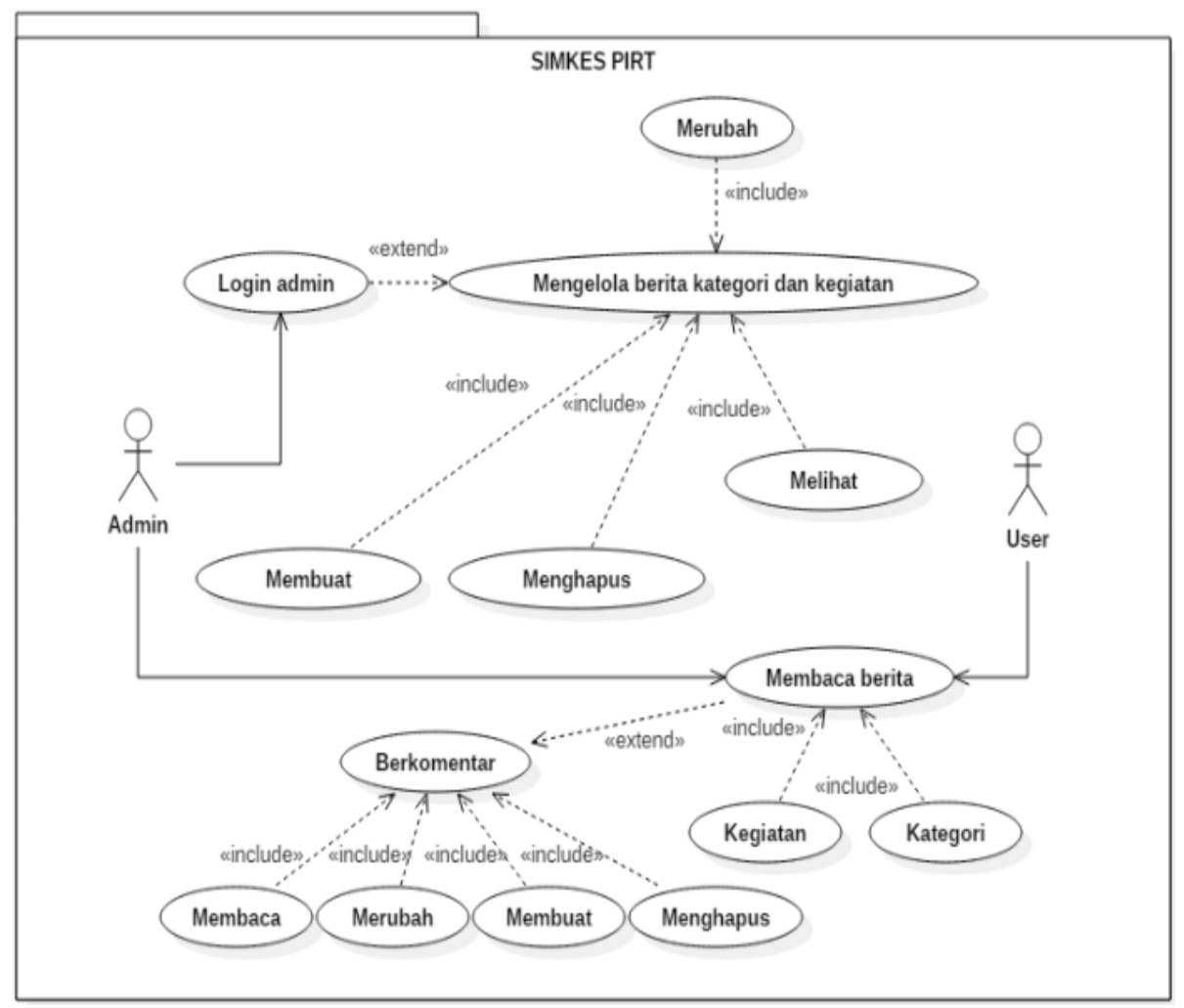

Gambar 2. Usecase diagram SIMKES P - IRT

Gambar 2 tersebut merupakan usecase diagram dari alur dari proses pengelolaan informasi dan penerimaan informasi. Dalam usecase tersebut terdapat 2 aktor yang mewakili antara pihak instansi dengan masyarakat. Pertama adalah seorang admin, seorang admin memiliki hak istimewa yaitu dapat melakukan segala operasi yang ada dalam aplikasi tersebut, karena hak akses penuh tersebut diberikan kepada pegawai atau pihak instansi tersebut. Seorang admin mampu melakukan login administrator, CRUD (Create, Read,
Update, Delete) berita, kategori, dan kegiatan. Aktor kedua adalah masyarakat, masyarakat disini dapat melihat berita, kategori, dan kegiatan yang telah diberikan oleh Dinas Kesehatan Kota Salatiga serta dapat memberikan komentar terhadap berita yang sudah dipublikasi. 




Gambar 3. Activity diagram admin

Pada Gambar 3 diagram tersebut merupakan gambaran seorang admin dari Dinas Kesehatan Kota Salatiga ketika mengunjungi website tersebut. Penjelasan dari sebuah diagram activity menunjukkan aktivitas sistem dalam bentuk kumpulan aksi-aksi, bagaimana masing-masing aksi tersebut dimulai, keputusan yang mungkin terjadi hingga berakhirnya aksi [13]. Pada awal dikunjungi website akan menampilkan gambar beranda dengan menu seperti pada umumnya dikunjungi oleh masyarakat. Menu tersebut menampilkan seluruh berita yang telah dipublikasi dan menu untuk menuju ke halaman administrator. Setelah seorang admin melakukan login administrator maka hak akses penuh website tersebut akan didapat, yaitu untuk melakukan CRUD (Create, Read, Update, Delete) pada berita yang akan dipublikasikan. Apabila seorang admin tidak melakukan login maka akses yang didapatkan hanyalah seperti website yang dikunjungi oleh masyarakat pada umumnya yaitu membaca berita yang telah terpublikasi.

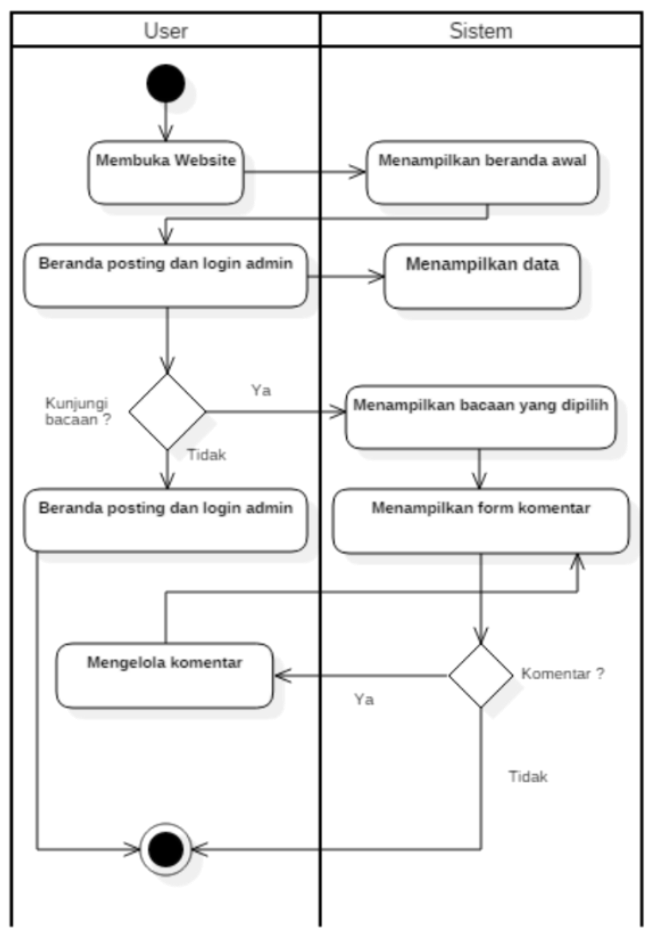

Gambar 4. Activity diagram use

Di dalam Gambar 4 activity diagram tersebut menjelaskan gambaran seorang user umum ketika mengunjungi website tersebut. Pada tampilan awal gambar beranda tersebut sama dengan halaman awal yang dibuka oleh seorang admin. Perbedaannya adalah seorang masyarakat tidak bisa mengakses halaman beranda admin karena dalam mengakses website tersebut pembuatan akun tidak dibuka secara umum melainkan hanya pihak-pihak terkait dengan Dinas Kesehatan Kota Salatiga. Ketika user mengunjungi sebuah halaman berita, maka muncul halaman yang berisi gambar berita dan isi dari berita. Selain dari itu terdapat form komentar setelah berita yang terletak dibawah teks dari berita. 


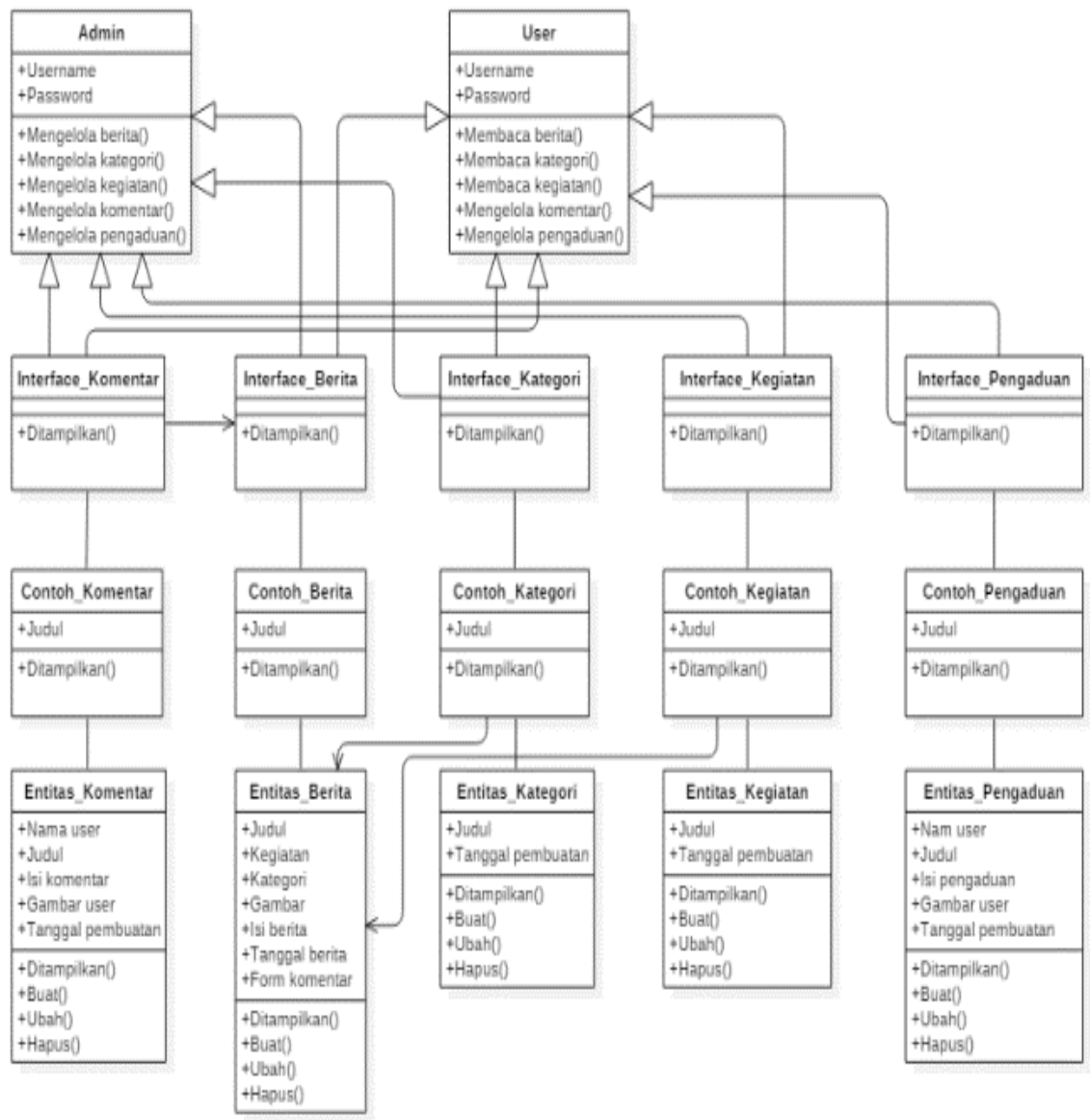

Gambar 5. Class diagram sistem

Class diagram adalah suatu spesifikasi jika diinstansiasi akan menghasilkan suatu objek serta merupakan inti dari pengembangan dan desain berorientasi objek (atribute / properti) suatu sistem, sekaligus memberikan pelayanan untuk memanipulasi keadaan tersebut (metode / fungsi). Class diagram juga menggambarkan suatu struktur dan deskripsi class, package dan objek beserta hubungan satu dengan lainnya seperti containment, pewarisan, asosiasi, dan lain-lain [14].

Gambar 5 merupakan class diagram yang menjelaskan bagian-bagian dari sistem yang dijelaskan berdasarkan kepemilikan atribut dan operasi yang dijalankan. Pertama seorang admin memiliki username dan password yang digunakan sebagai akses login dan mengelola seluruh informasi meliputi berita, kegiatan, kategori, dan juga komentar. Setelah itu seorang user umum memiliki akses yang meliputi membaca berita, kegiatan, kategori, dan juga mengelola komentar. Dalam mengelola komentar, seorang user akan melakukan login dengan akun sosial media yang namanya akan tercantum pada form komentar. Pada bagian komentar, letaknya terdapat pada bagian setelah isi berita sehingga komentar tidak dapat berdiri sendiri dan harus berada pada isi berita. Begitu juga pada kategori dan kegiatan, sebuah berita yang akan dipublikasi pasti berisi dua penanda tersebut, karena penanda tersebut merupakan syarat suatu berita dapat dipublikasikan dalam sistem.

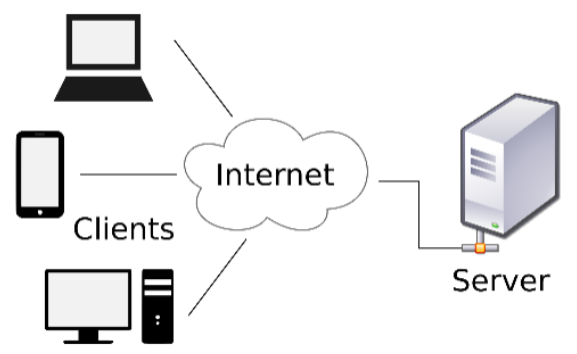

Gambar 6. Arsitektur Sistem

Gambar 6 menjelaskan arsitektur sistem informasi ini menggunakan arsitektur client-server. Maksud dari arsitektur ini adalah di dalamnya terdapat 2 komponen sebagai klien dan server, klien juga bisa disebut dengan front-end, sementara komponen server ialah back-end. Di dalam bahasa pemgroman yang digunakan terdapat sebuah skrip yang berguna untuk melakukan pemanggilan terhadap suatu halaman, hal itu disebut dengan front-end. Sedangkan pada fungsi halaman tertentu menjadi sebuah parameter untuk menampilkan halaman yang akan diminta, hal itu disebut dengan back-end. Sebagian besar bahasa pemrograman yang digunakan dalam sistem adalah bahasa pemrograman PHP. 
Skrip didalam bahasa tersebut berguna dalam membangun atau mendesain sebuah aplikasi website yang akan berjalan pada web browser sebagai server dari permintaan klien untuk ditampilkan. Sehingga data yang akan ditampilkan pada klien akan berjalan melalui web server disetiap komputer.

\section{HASIL DAN PEMBAHASAN}

Sebelum masuk kedalam penjelasan, sebelumnya akan membahas tentang Framework Laravel dan juga android. Framework Laravel memiliki 3 struktur bagian yang terdiri antara model, view, dan controller (MVC). Model adalah sebuah perantara penghubung yang menghubungkan antara controller dan database, pada struktur laravel model tersebut merupakan sebuah skrip PHP yang menghubungkan antara program dengan database sehingga dapat diatur melalui controller. Sedangkan view merupakan sebuah tampilan yang merepresentasikan sebuah layout terhadap user. Controller adalah sebuah penghubung antara view dengan model, artinya adalah controller merupakan sebuah skrip yang berguna mengendalikan antara hubungan data pada database dengan tampilan yang diterima oleh user sehingga saling terintegrasi. Didalam framework terdapat folder bernama database, folder tersebut berguna menampung skrip yang membentuk struktur database program yang disebut dengan model. Selanjutnya terdapat folder bernama resources, folder tersebut menampung bagian dari view program yang berisi dengan layout-layout guna menampilkan program. Dan folder berikutnya adalah folder controller, dimana folder tersebut berisikan skrip yang gunanya menjalankan program dan menghubungkan antara view dengan model.

Konsep dalam teknologi mobile android, dalam pengembangan dari aplikasi mobile tersebut juga memiliki fungsi-fungsi yang sama yaitu terdiri antara model, view, dan controller, hanya saja android memiliki cara pendeklarasian yang berbeda. Bagian dari view merupakan interface dari sebuah activity, dalam pembentukan file view tersebut berada pada file layout berformat .XML, gunanya untuk membuat rancangan desain sistem atau sebagai front-end dari sistem. Dan activity merupakan file yang berisi controller atau fungsi-fungsi pemanggilan pada suatu program yang berjalan, biasanya ditandai dengan file MainActivity.java, atau bisa disebut dengan back-end sistem. Sedangkan database dari android tersebut dideklarasikan melalui libary tertentu yang dihubungkan oleh suatu controller dalam mengeksekusi program untuk ditampilkan pada layout.

Hasil penelitian yang sudah dilakukan, sebuah sistem informasi ini akan dibangun dengan menggunakan
Framework Laravel yang digunakan dalam mengembangkan website, sedangkan untuk platform pengembang aplikasi mobile menggunakan Android Studio. Didalam sistem informasi yang sudah dibuat terdapat halaman website berupa beranda yang dilengkapi dengan navigasi, tabel kegiatan dan kategori, serta ruang komentar untuk pengguna maupun admin. Di bawah ini merupakan tampilan dari website beranda SIMKES PIRT.

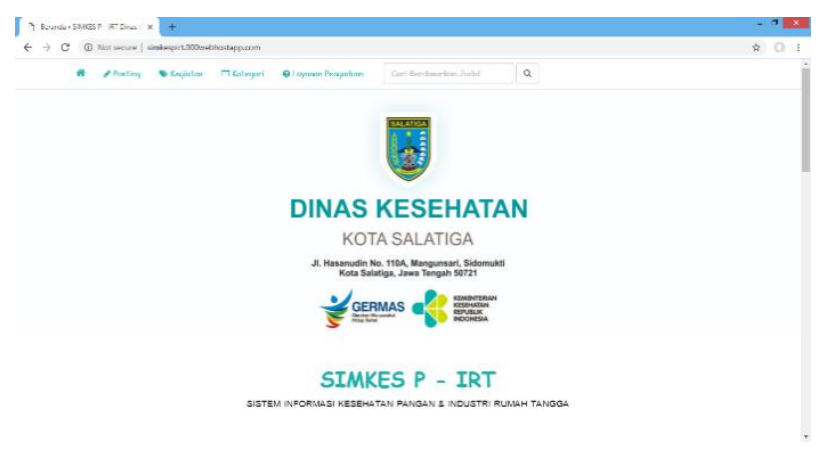

Gambar 7. Beranda SIMKES P - IRT

Gambar 7 merupakan bagian halaman beranda yang terdiri antara lain bagian navigasi link yang berisi menu untuk menuju ke berita, kegiatan, kategori, layanan pengaduan, dan sistem pencarian berita atau informasi. Setelah itu bagian header dari website terdiri dari logo dan gambar dari website.

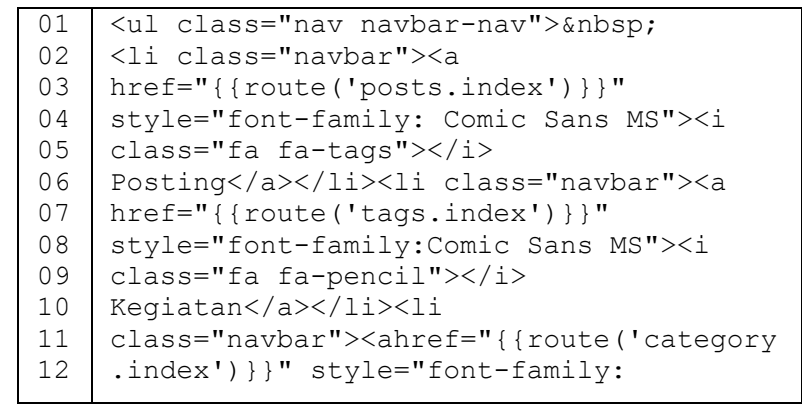

Kode program 1. Source code untuk menampilkan bagian navigasi.

Kode program 1 merupakan bagian untuk menampilkan menu navigasi dan halaman tujuan dari link tersebut apabila dipilih. Dalam fungsi pemanggilan halaman tersebut menggunakan folder bernama route pada Framework Laravel guna mengakses fungsi controller. Didalam route tersebut terdapat sebuah file Web.php yang berisi skrip parameter untuk menjalankan fungsi controller. 


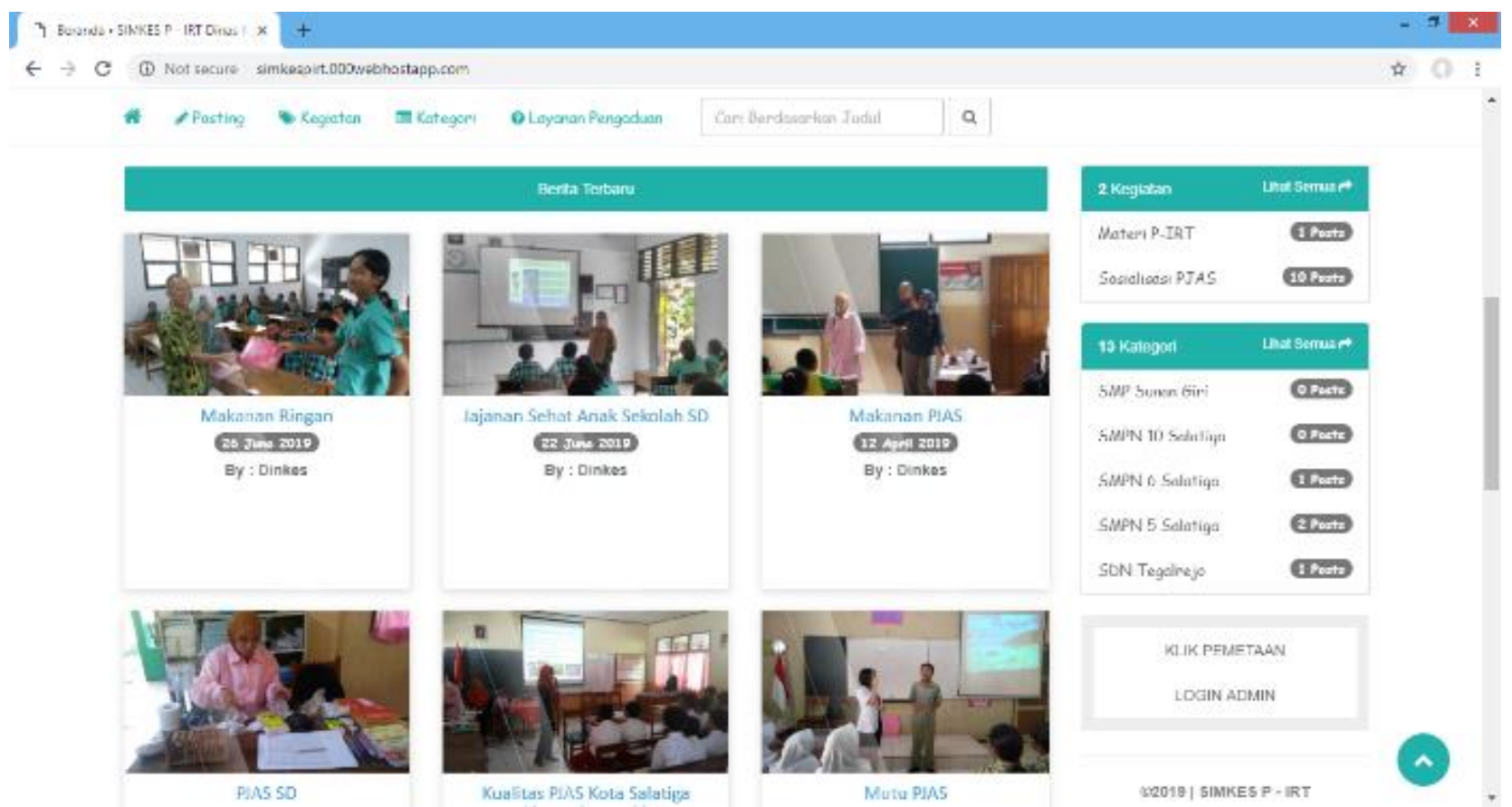

Gambar 8. Berita Terbaru Beranda SIMKES P-IRT

Pada gambar 8 menjelaskan bahwa di bagian beranda terdapat tampilan kolom berita baru, tabel kegiatan, dan tabel kategori. Halaman ini merupakan bagian dari halaman beranda yang letaknya dibawah logo dan gambar dari website yang dijelaskan pada gambar sebelumnya. Terdapat juga tabel kegiatan dan kategori yang berfungsi sebagai pintasan menuju ke halaman yang berada pada suatu kategori dan kegiatan yang sudah dikelompokkan, hal tersebut merupakan yang disebut dengan konsep collaborative filtering. Selain pintasan kategori dan kegiatan terdapat pintasan menuju login administrator yang gunanya untuk masuk ke halaman login administrator oleh admin. Dalam desain sistem tersebut daftar berita dibentuk kotak-kotak agar tampilan awal dari beranda lebih terkesan rapi, simpel, dan menarik terhadap pembaca.

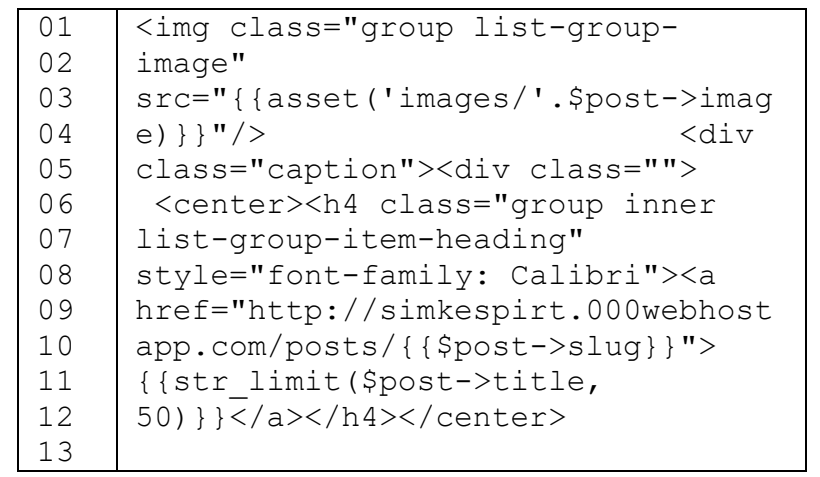

Kode program 2. Menampilkan bagian kolom berita terbaru.
Kode program 2 merupakan bagian dari fungsi-fungsi menampilkan kolom berita terbaru. Pada baris pertama adalah fungsi yang membuat tampilan berita menjadi bentuk kotak-kotak atau grid. Pada baris pertama berfungsi menampilkan gambar yang disertai dalam pembuatan berita. Dan baris selanjutnya adalah fungsi menampilkan judul dan tanggal dari pembuatan berita tersebut. Pemanggilan dari gambar tersebut ditandai dengan kode \$post->image yang artinya menampilkan gambar dari sebuah posting melalui database. Sedangkan pemanggilan judul ditandai dengan kode $\{\{$ p post->slug\} , yang artinya memanggil nama dari sebuah posting yang berhasil diunggah dari database dan membatasi jumlah karakter yang akan ditampilkan pada layar ditandai dengan kode \{str_limit(\$post->title, 50)\}\}.

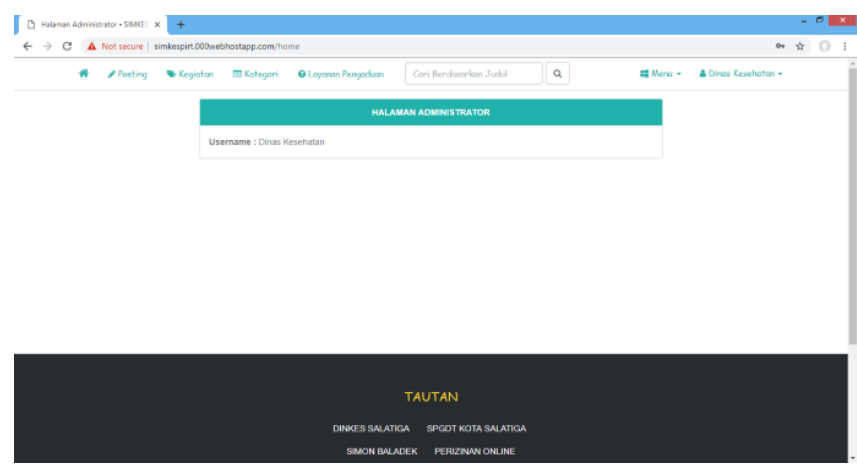

Gambar 9. Beranda Admin SIMKES P-IRT 
Gambar 9 merupakan gambar dari beranda admin, beranda admin adalah halaman dimana seorang admin telah melakukan login administrator. Di dalam halaman admin tersebut, terdapat username yang tercantum sebagai akun yang telah masuk dan dapat mengakses penuh terhadap website tersebut. Setelah melakukan login, pada navigasi website tersebut muncul menu baru yaitu menu CRUD (Create, Read, Update, Delete) yang digunakan untuk membuat, membaca, memodifikasi, dan menghapus berita. Selain itu seorang admin juga dapat mengelola data kategori dan juga kegiatan sebagai penanda berita. Menu yang lain adalah terdapat navigasi logout ketika seorang admin ingin mengakhiri pada sesi administrator.
Kode program 3 merupakan kode yang berfungsi menampilkan keterangan admin telah berhasil masuk ke dalam administrator yaitu ditandai dengan mencantumkan username yang sudah melakukan login, hal tersebut ditandai dengan kode $<$ b $>$ Username : $</$ b $>\{\{$ Auth: :user ()$->$ name $\}\}$ yaitu menampilkan nama user admin yang telah terdaftar pada database. Pada baris kode ke-4 sampai baris ke-5 merupakan kode yang menandakan seseorang sedang berada pada sesi administrator.

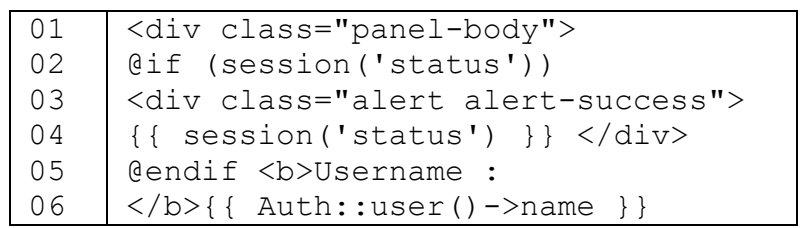

Kode program 3. Menampilkan halaman administrator.

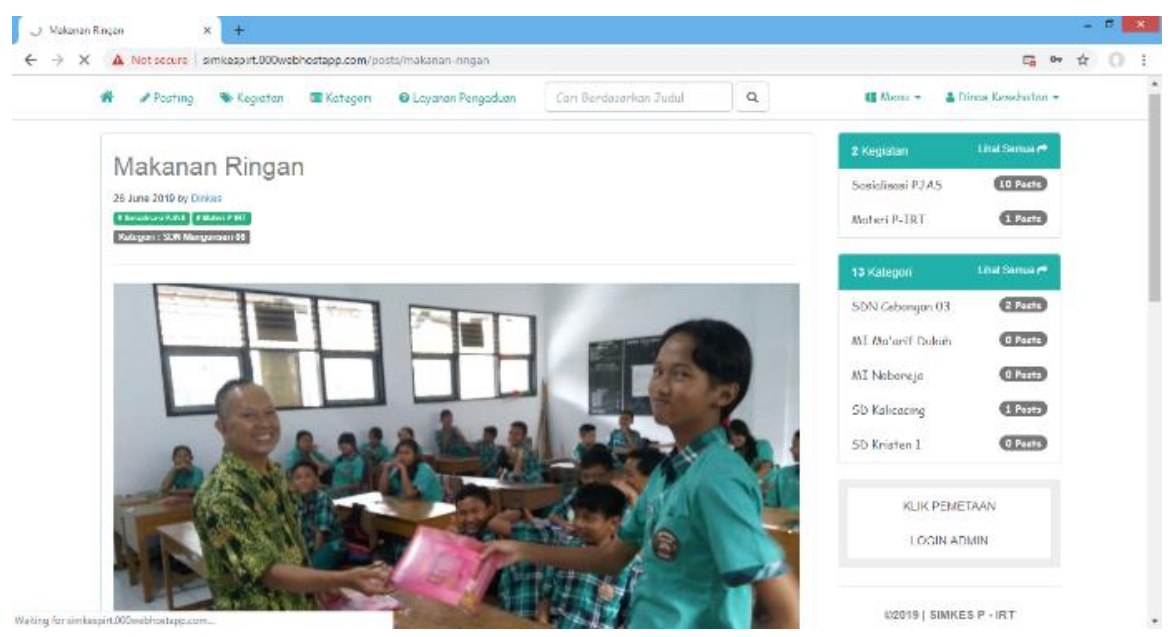

Gambar 10. Isi berita

Gambar 10 menunjukkan halaman isi dari berita yang telah dipublikasi oleh admin. Di dalam halaman tersebut terdapat kolom kegiatan, kategori, dan juga login untuk admin. Setelah isi berita tersebut, dibawahnya terdapat form komentar dan diskusi untuk pembaca. Pada isi berita tersebut terdapat judul dengan ukuran teks besar, dan juga label untuk penanda kegiatan dan kategori yang masing-masing berwarna hijau dan abu-abu. Pada isi berita yang dipublikasi bisa berupa teks dan gambar. Dalam halaman isi berita tersebut masih menampilkan bagian tabel kegiatan dan kategori, gunanya adalah sebagai pintasan apabila seorang user akan membuka suatu halaman pada tabel yang tersedia.

\begin{tabular}{|c|c|}
\hline 01 & <h2 class="handle" $>\{$ \{\$posts- \\
\hline 02 & $>$ title $\}\}\langle/$ h 2$\rangle$ \\
\hline 03 & <div class="post-meta"><div \\
\hline 04 & class="asker-meta"> \\
\hline 05 & $\langle$ span $>\{\{$ date ('j $F$ Y', \\
\hline 06 & strtotime (\$posts- \\
\hline 07 & $>$ created_at) ) $\}\}\langle/$ span $\rangle$ \\
\hline 08 & $\langle/$ div $\rangle\langle$ div class="tags" $\rangle$ eforeach \\
\hline 09 & (\$posts->tags as \$tag)<span \\
\hline 10 & class="label label-success">\# \\
\hline 11 & $\{\{\$$ tag->name $\}\}</$ span $>$ dendforeach \\
\hline 12 & $</$ div $\rangle\langle$ h4 class="label label- \\
\hline 13 & default">Kategori : \{f\$posts- \\
\hline 14 & $>$ category $->$ name $\}\langle/$ h 4$\rangle$ \\
\hline
\end{tabular}

Kode program 4. Menampilkan isi berita. 
Kode program 4 merupakan kode yang berfungsi menampilkan bagian dari isi berita ketika suatu berita telah dipilih. Pada baris kode pertama sampai ke-2 berfungsi sebagai menampilkan judul dari berita, kemudian pada baris selanjutnya merupakan fungsi menampilkan tanggal dan waktu berita tersebut dipublikasikan. Dan yang terakhir merupakan label yang berisi penanda kategori dan kegiatan.

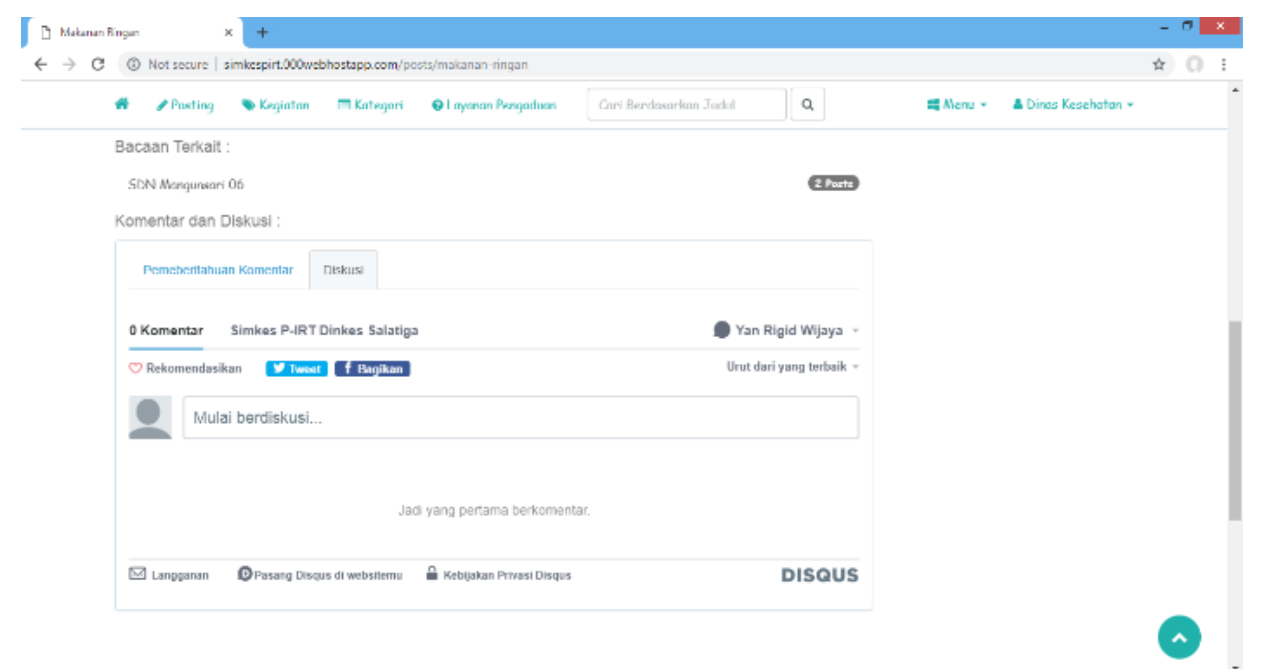

Gambar 11. Form komentar pada berita

Gambar 11 merupakan bagian form komentar yang terletak setelah isi dari berita. Pada form komentar yang berada di dalam berita tersebut merupakan tempat berdiskusi yang dapat digunakan oleh umum maupun oleh admin. Untuk melakukan diskusi seseorang harus melakukan login terhadap akunnya, apabila seseorang belum mempunyai akun maka dapat melakukan pendaftaran dengan akun google yang dimiliki atau dengan akun sosial media seperti facebook, twitter, dan lainnya.

\begin{tabular}{|c|c|}
\hline 01 & $\langle$ div id="disqus_thread" $\langle/$ div $\rangle$ \\
\hline 02 & <script>(function() \& // DON'T \\
\hline 03 & EDIT BELOW THIS LINE var $\mathrm{d}=$ \\
\hline 04 & document, $s=$ \\
\hline 05 & d.createElement('script'); $\mathbf{s}$ src = \\
\hline 06 & 'https://simkespirt.disqus.com/emb \\
\hline 07 & ed.js';s.setAttribute ('data- \\
\hline 08 & timestamp', +new Date()); (d.head \\
\hline 09 & || d.body) appendChild(s);\}) (); \\
\hline 10 & $\langle/$ script $\rangle\langle$ noscript $\rangle$ Please enable \\
\hline
\end{tabular}

Kode program 5. Menampilkan bagian komentar

Kode program 5 di atas adalah merupakan sebuah kode yang secara otomatis terbuat ketika akan memasukkan plugin disqus ke dalam situs kita. Kode tersebut adalah kode yang terbentuk ketika kita memasuki situs disqus.com kemudian memilih fitur pasang ke dalam website kita. Hal pertama yang dilakukan adalah kita harus membuat akun terlebih dahulu ke dalam platform disqus, setelah itu baru kita gunakan fitur pasang disqus komentar tersebut ke website yang kita miliki. Kode yang muncul akan otomatis dihasilkan melalui fitur pada disqus yang dapat kita pasang kedalam website kita.

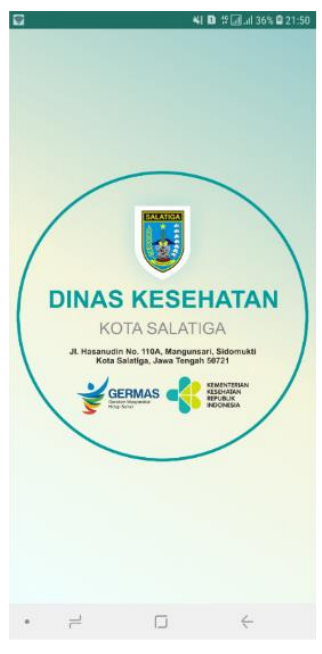

1

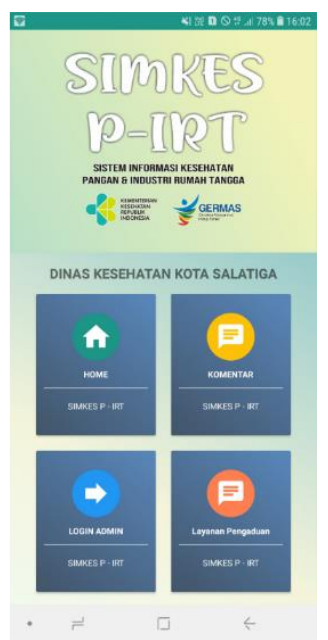

2
Gambar 12. Tampilan menu aplikasi versi android.

Gambar 12 adalah aplikasi website yang telah dirancang dalam bentuk mobile application. Gambar nomor 1 di atas merupakan tampilan dari splash screen atau biasa disebut halaman sambutan aplikasi. Pada gambar ke 2 merupakan tampilan beranda dari aplikasi mobile yang berisi 4 tombol menu, yaitu beranda, komentar, login administrator, dan layanan pengaduan. Setiap tombol tersebut memiliki fungsi yang berbeda-beda, pertama tombol home akan masuk ke halaman beranda yang terdapat di dalam website yang sudah dijelaskan sebelumnya. Berikutnya tombol komentar dimana tombol tersebut menuju ke halaman komentar yang ada pada website, lebih tepatnya adalah menuju ke situs disqus.com 
sebagai platform komentar yang digunakan. Kedua tombol yang lainnya merupakan tombol yang menuju ke halaman login admin dan layanan pengaduan yang sesuai dengan website yang ketika dibuka dalam komputer. Dalam mendesain sistem tersebut platform yang digunakan adalah Android Studio. Untuk membuat tombol yang tersusun kotak-kotak tersebut menggunakan card view dari Android Studio, dan masing-masing background yang mewarnai dari tombol tersebut diatur pada folder drawable. Folder drawable tersebut merupakan sebuah direktori penyimpanan yang digunakan dalam memanggil sebuah halaman yang berisi tentang komposisi dalam membentuk sebuah desain dari aplikasi, misalnya gambar, warna background, dan lainlain.

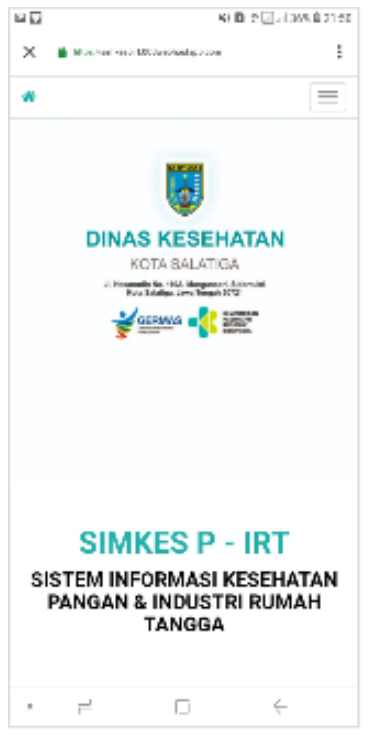

1

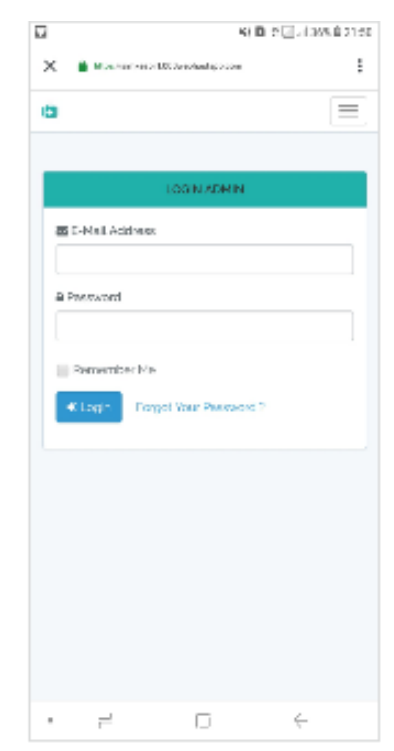

2

Gambar bagian 2 di atas juga merupakan menu utama di dalam aplikasi tersebut. Menu-menu tersebut dalam fungsi menampilkan layout diatur dalam file activity_main.xml, kemudian dari sisi back-end atau fungsi yang digunakan untuk bagaimana tombol tersebut dapat mengeksekusi permintaan user sehingga dapat menampilkan halaman lain yang diinginkan tersebut diatur dalam file MainActivity.java, di dalamnya diatur bagaimana alur setiap tombol tersebut bekerja agar menampilkan layout dari custom tab view yang berisi alamat dari aplikasi website yang sudah dirancang sebelumnya. Fitur dari custom tab view akan dijelaskan secara lebih detail pada gambar berikutnya.

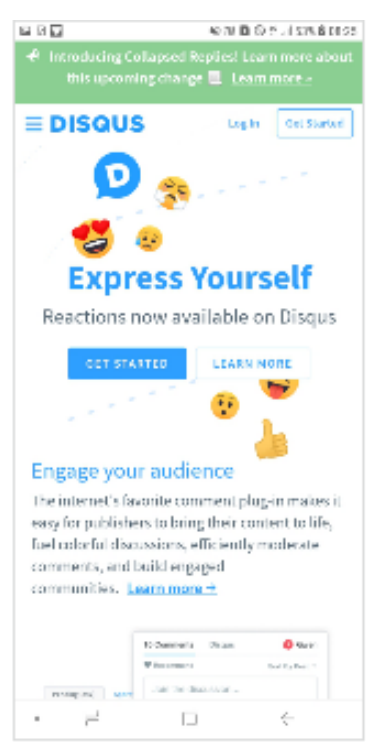

3



4

Gambar 13. Isi menu SIMKES P-IRT versi android.

Gambar 13 merupakan isi tampilan dari menu beranda sebelumnya. Gambar bagian 1 adalah menu home, 2 login administrator, 3 komentar, dan 4 menu layanan pengaduan. Pada menu tersebut menerapkan custom tab view pada Android Studio. Custom chrome tab view merupakan sebuah teknologi berbasis webview yang memiliki cara menampilkan tab baru atau halaman website lain dalam satu bentuk layout, sehingga menjadi seperti layaknya aplikasi google chrome pada komputer, sisi perbedaannya adalah sebuah tab baru akan muncul pada satu layar. Ketika membuka halaman lain dalam satu layout dapat dibuka bersama dalam satu custom tab. Contohnya ketika melakukan login akun google, apabila pada halaman web browser akan muncul tab baru sebagai tampilan login ke dalam akun yang akan digunakan, apabila di dalam aplikasi android maka halaman tersebut dapat terbuka dalam satu layout dan bisa ditutup kembali ke halaman sebelumnya. Apabila seorang admin ingin melakukan login administrator maka bisa dapat mengunjungi link yang ada pada bagian setelah tabel kategori dan berita seperti pada website.

Setelah itu menu admin dan navigasi berada pada bagian paling atas yang dapat diakses dengan menekan tombol disudut kanan bergaris tiga. Navigasi yang ada tersebut sama persis dengan navigasi pada saat kita membuka website pada komputer atau laptop. Apabila tidak melakukan login, maka menu navigasi hanya muncul seperti pada biasanya tidak dilengkapi dengan menu admin.

Tahapan pengujian sistem menggunakan pengujian alpha dan beta. Pengujian ini memproyeksikan kedua belah pihak yang berada dalam keterlibatan proses pengujian sehingga layak dan berhasil digunakan. Pengujian alpha merupakan pengujian yang dilakukan melalui sisi developer/programmer aplikasi, pengujian tersebut meliputi pengujian fungsi dari aplikasi maupun penanganan sebuah kesalahan / error pada aplikasi. Selanjutnya, pengujian alpha 
pada sistem yang dibangun dapat dilihat pada Tabel I di bawah ini.

TABEL I

TABEL PENGUJIAN ALPHA PADA SISTEM

\begin{tabular}{|c|c|c|c|}
\hline Input & Harapan & Output & Kesimpulan \\
\hline $\begin{array}{l}\text { Tombol } \\
\text { login }\end{array}$ & $\begin{array}{c}\text { Masuk ke } \\
\text { halaman } \\
\text { administrator }\end{array}$ & $\begin{array}{c}\text { Masuk ke } \\
\text { halaman } \\
\text { administrator }\end{array}$ & Sesuai \\
\hline $\begin{array}{l}\text { Tombol } \\
\text { posting }\end{array}$ & $\begin{array}{c}\text { Masuk ke } \\
\text { halaman } \\
\text { semua posting }\end{array}$ & $\begin{array}{c}\text { Masuk ke } \\
\text { halaman } \\
\text { semua posting }\end{array}$ & Sesuai \\
\hline $\begin{array}{l}\text { Tombol } \\
\text { kategori }\end{array}$ & $\begin{array}{c}\text { Masuk } \\
\text { halaman } \\
\text { kategori }\end{array}$ & $\begin{array}{c}\text { Masuk } \\
\text { halaman } \\
\text { kategori }\end{array}$ & Sesuai \\
\hline $\begin{array}{l}\text { Tombol } \\
\text { beranda }\end{array}$ & $\begin{array}{c}\text { Masuk } \\
\text { halaman } \\
\text { beranda awal } \\
\end{array}$ & $\begin{array}{c}\text { Masuk } \\
\text { halaman } \\
\text { beranda awal } \\
\end{array}$ & Sesuai \\
\hline $\begin{array}{l}\text { Tombol } \\
\text { kegiatan }\end{array}$ & $\begin{array}{c}\text { Masuk } \\
\text { halaman } \\
\text { kegiatan }\end{array}$ & $\begin{array}{c}\text { Masuk } \\
\text { halaman } \\
\text { kegiatan }\end{array}$ & Sesuai \\
\hline $\begin{array}{c}\text { Tombol } \\
\text { pengaduan }\end{array}$ & $\begin{array}{c}\text { Masuk } \\
\text { halaman } \\
\text { pengaduan }\end{array}$ & $\begin{array}{c}\text { Masuk } \\
\text { halaman } \\
\text { pengaduan }\end{array}$ & Sesuai \\
\hline Kelola post & $\begin{array}{c}\text { Masuk } \\
\text { halaman kelola } \\
\text { post }\end{array}$ & $\begin{array}{c}\text { Masuk } \\
\text { halaman kelola } \\
\text { post }\end{array}$ & Sesuai \\
\hline $\begin{array}{c}\text { Kelola } \\
\text { kategori }\end{array}$ & $\begin{array}{c}\text { Masuk } \\
\text { halaman kelola } \\
\text { kategori }\end{array}$ & $\begin{array}{c}\text { Masuk } \\
\text { halaman kelola } \\
\text { kategori } \\
\end{array}$ & Sesuai \\
\hline $\begin{array}{l}\text { Kelola } \\
\text { kegiatan }\end{array}$ & $\begin{array}{c}\text { Masuk } \\
\text { halaman kelola } \\
\text { kegiatan }\end{array}$ & $\begin{array}{c}\text { Masuk } \\
\text { halaman kelola } \\
\text { kegiatan }\end{array}$ & Sesuai \\
\hline $\begin{array}{l}\text { Beranda } \\
\text { admin }\end{array}$ & $\begin{array}{c}\text { Masuk } \\
\text { halaman admin }\end{array}$ & $\begin{array}{c}\text { Masuk } \\
\text { halaman admin }\end{array}$ & Sesuai \\
\hline $\begin{array}{c}\text { Upload } \\
\text { tanpa salah } \\
\text { satu dari } \\
\text { (judul, } \\
\text { kategori, } \\
\text { kegiatan, } \\
\text { gambar, dan } \\
\text { isi) } \\
\end{array}$ & $\begin{array}{l}\text { Memunculkan } \\
\text { pemberitahuan } \\
\text { error sebagai } \\
\text { prasyarat } \\
\text { kelengkapan } \\
\text { upload }\end{array}$ & $\begin{array}{l}\text { Memunculkan } \\
\text { pemberitahuan } \\
\text { error sebagai } \\
\text { prasyarat } \\
\text { kelengkapan } \\
\text { upload }\end{array}$ & Sesuai \\
\hline Komentar & $\begin{array}{l}\text { Masuk ruang } \\
\text { komentar }\end{array}$ & $\begin{array}{c}\text { Masuk ruang } \\
\text { komentar }\end{array}$ & Sesuai \\
\hline $\begin{array}{l}\text { Menyimpan } \\
\text { penanda } \\
\text { kategori } \\
\text { tanpa nama }\end{array}$ & $\begin{array}{c}\text { Memunculkan } \\
\text { error sebagai } \\
\text { salah satu } \\
\text { prasyarat } \\
\text { upload } \\
\text { penanda } \\
\end{array}$ & $\begin{array}{c}\text { Memunculkan } \\
\text { error sebagai } \\
\text { salah satu } \\
\text { prasyarat } \\
\text { upload } \\
\text { penanda } \\
\end{array}$ & Sesuai \\
\hline $\begin{array}{l}\text { Menyimpan } \\
\text { penanda } \\
\text { kegiatan } \\
\text { tanpa nama }\end{array}$ & $\begin{array}{c}\text { Memunculkan } \\
\text { error sebagai } \\
\text { salah satu } \\
\text { prasyarat } \\
\text { upload } \\
\text { penanda }\end{array}$ & $\begin{array}{l}\text { Memunculkan } \\
\text { error sebagai } \\
\text { salah satu } \\
\text { prasyarat } \\
\text { upload } \\
\text { penanda } \\
\end{array}$ & Sesuai \\
\hline $\begin{array}{l}\text { Memilih } \\
\text { post }\end{array}$ & $\begin{array}{l}\text { Menampilkan } \\
\text { isi post }\end{array}$ & $\begin{array}{l}\text { Menampilkan } \\
\text { isi post }\end{array}$ & Sesuai \\
\hline $\begin{array}{l}\text { Logout } \\
\text { admin }\end{array}$ & $\begin{array}{c}\text { Masuk ke } \\
\text { beranda awal }\end{array}$ & $\begin{array}{c}\text { Masuk ke } \\
\text { beranda awal }\end{array}$ & Sesuai \\
\hline
\end{tabular}

Tahapan pengujian sistem selanjutnya adalah pengujian beta, atau pengujian yang dilakukan oleh pengguna. Pengujian beta berguna untuk mendapatkan hasil yang diharapkan oleh pengguna aplikasi apakah aplikasi tersebut sesuai dengan yang diinginkan dan telah memenuhi kriteria pengguna. Pengujian tersebut dilakukan melalui tahapan wawancara dan observasi langsung kepada pihak Dinas Kesehatan Kota Salatiga melalui Kepala Seksi Farmamin dan Perbekes. Pengujian beta pada sistem melalui responden secara langsung dapat dilihat pada Tabel II di bawah ini.

TABEL II

TABEL PENGUJIAN BETA PADA SISTEM

\begin{tabular}{|l|l|l|l|l|l|l|}
\hline \multicolumn{1}{|c|}{ Pertanyaan } & SS & S & N & TS & STS & Skor \\
\hline $\begin{array}{l}\text { Tampilan dari sistem } \\
\text { informasi website dapat } \\
\text { mempermudah } \\
\text { pengguna umum } \\
\text { menemukan informasi. }\end{array}$ & $\checkmark$ & & & & & 100 \\
\hline $\begin{array}{l}\text { Sistem informasi yang } \\
\text { dibangun dapat } \\
\text { menyampaikan } \\
\text { informasi sesuai dengan } \\
\text { kebutuhan. }\end{array}$ & & & & & & 80 \\
\hline $\begin{array}{l}\text { Cara pengoperasian } \\
\text { sistem informasi oleh } \\
\text { pihak admin cukup } \\
\text { mudah. }\end{array}$ & $\checkmark$ & & & & & \\
\hline $\begin{array}{l}\text { Cara pengoperasian } \\
\text { sistem informasi oleh } \\
\text { pihak umum / } \\
\text { masyarakat cukup } \\
\text { mudah. }\end{array}$ & $\checkmark$ & $\checkmark$ & & & & 100 \\
\hline $\begin{array}{l}\text { Apakah bentuk } \\
\text { informasi yang diterima } \\
\text { dan ditampilkan sudah } \\
\text { cukup jelas melalui } \\
\text { sistem tersebut. }\end{array}$ & $\checkmark$ & & & & & \\
\hline
\end{tabular}

Keterangan pilihan jawaban pada Tabel II adalah

$\begin{array}{ll}\text { SS } & \text { : Sangat setuju } \\ \text { S } & \text { : Setuju } \\ \text { N } & \text { : Netral } \\ \text { TS } & \text { : Tidak setuju } \\ \text { STS } & \text { : Sangat tidak setuju }\end{array}$

Berdasarkan nilai jawaban melalui sebuah kuisioner pada tabel menunjukan bahwa pihak instansi telah menyetujui kurang lebih $92 \%$ dari pembangunan sistem informasi tersebut.

\section{KESIMPULAN}

Berdasarkan penelitian yang telah dilakukan, perancangan dan implementasi sistem informasi terhadap instansi tersebut memiliki manfaat yang dapat menunjang kinerja sistem pada pemerintahan dan pada pelayanan terhadap masyarakat. Setelah melalui tahapan pengujian dari pengembang sistem, sistem tersebut telah mampu beroperasi dengan baik pada webs server yang ada pada tiap-tiap komputer. Tahapan pengujian alpha atau tahap pengujian dimana program akan didesain ulang apabila masih memiliki bug atau error pada sistem telah dilalui sehingga website tersebut berhasil berjalan pada sistem web server tanpa ada error pada bagian 
fungsi-fungsi tertentu, setelah itu dilakukan ketahap pengujian beta atau dimana pengujian tersebut melibatkan pengguna dalam mengimplementasikan sistem yang sudah dapat beroperasi. Pengujian yang telah berhasil dilakukan oleh pihak klien atau instansi pemerintah menyimpulkan bahwa sistem tersebut telah siap digunakan dan telah dilakukan beberapa percobaan dalam memberikan informasi melalui sistem tersebut. Dalam desain yang sudah dibuat, pengguna telah mampu mengoperasikan dengan baik dan sudah merasa nyaman dengan sistem yang telah dibuat. Setelah pihak instansi melakukan percobaan, masyarakat umum juga telah melakukan percobaan mengakses sistem tersebut. Hasil yang didapatkan masyarakat umum sudah merasakan kemudahan dalam mengaksesnya dan merasakan nyaman dengan desain sistem yang sudah dirancang. Sistem tersebut sudah dapat beroperasi dengan lancar tanpa ada salah satu fungsi yang error di dalam akses setiap sistem. Hal tersebut merupakan sebuah langkah dimana seseorang perlu memperhatikan teknologi dan segala kemajuannya sehingga berdampak baik terhadap kehidupannya.

\section{DAFTAR PUSTAKA}

[1] Kurniawan, Dhika A, Rahma Yudi Astuti. "Pendampingan Pengurusan Izin PIRT Sebagai Langkah Awal Pengembangan dan Perluasan Pasar Bagi Produk Lokal IKM Ponorogo", Khadimul Ummah, vol. 1, no 2, pp. 56-64, 2018.

[2] B, Fihma Sahrul, Muhammad Asri Safi'ie, dan Ovide Decroly. "Implementasi Sistem Informasi Akademik Berbasis Web Menggunakan Framework Laravel". TRANSFORMASI Jurnal Informasi \& Pengembangan Iptek, vol. 12, no 1, pp. 46 - 50, 2016.
[3] Dharma, Y.A, Tanone, R. "MSME Recommendation Application using Collaborative Filtering Method and Realtime Database (Case Study : Salatiga City)", International Conference on Electrical Engineering and Computer Science (ICECOS), Proceeding ICECOS, 2018, p. 361.

[4] Naista, D. Codeigniter Vs Laravel. Yogyakarta : CV. Lokomedia, 2017.

[5] Burnette, Ed. Hello Android, Introducing Google's Mobile Development Platform, England: The Pragmatic Bookshelf, 2008.

[6] Putra, Ferdian Sukarno, Purnama, Bambang Eka, Wardati, Indah Uly. "Pembangunan Sistem Informasi Pendaftaran Mahasiswa Baru Pada Universitas Terbuka Pacitan", Indonesian Journal on Networking and Security, vol 1, no 1, pp. 1-6, 2013.

[7] Techterms.com. (2014) Web Application. [Online]. Tersedia : http://techterms.com/definition/web_application

[8] Wicaksono, E, Evangs, M. (2016). Aplikasi Kuliner Salatiga Berbasis Web Menggunakan Framework Laravel. [Online]. Tersedia :http://repository.uksw.edu/bitstream/123456789/11228/2/ T1 672009276 Full\%20text.pdf

[9] Hermanu B. (2015). Pengembangan Sistem Keamanan Pangan Terpadu Dalam Mewujudkan Efektivitas Implementasi Izin Edar Produk Pangan Industri Rumah Tangga (PIRT). [Online]. Tersedia : https://media.neliti.com/media/publications/174387-ID-none.pdf

[10] Sugiyono. Metode Penelitian Kuantitatif, Kualitatif dan $R \& D$, Bandung : Alfabeta, 2013.

[11] Sugiyono. Metode Penelitian Kuantitatif, Kualitatif dan $R \& D$. Bandung: Alfabeta, 2012.

[12] Pressman, Roger S. Rekayasa Perangkat Lunak. Yogyakarta : Andi, 2012.

[13] Suendri. "Implementasi Diagram UML (Unified Modelling Language) Pada Perancangan Sistem Informasi Remunerasi Dosen Dengan Database Oracle (Studi Kasus: UIN Sumatera Utara Medan)". Jurnal Ilmu Komputer dan Informatika, vol.3, no 1, pp. 1 - 9, 2018.

[14] Zulkifli. "Rancang Bangun Website E - Learning dengan Pemodelan UML". Journal of Information Technology and Computer Science, vol. 1, no 2, pp. 159- 167, 2018. 